\title{
PENINGKATAN PENGETAHUAN MURID SMA TERKAIT KESEHATAN REPRODUKSI UNTUK MENCEGAH STUNTING DI DESA MAYANGREJO, KALITIDU
}

\section{KNOWLEDGE IMPROVEMENT OF HIGH SCHOOL STUDENTS ABOUT REPRODUCTIVE HEALTH TO PREVENT STUNTING IN MAYANGREJO, KALITIDU}

\section{Astri Dewi Choirina}

Departemen Biostatistika dan Kependudukan Fakultas Kesehatan Masyarakat Universitas Airlangga

email: astri.dewi.choirina-2016@fkm.unair.ac.id

\begin{abstract}
The period of the first 1000 days is often called the window of opportunities or often called the golden period which is a determinant of the quality of health in the next lifetime. Unfortunately, in every 1000 HPK there are various health problems that affect the health of the baby, which one of the problems is stunting. Stunting is a malnutrition condition related to insufficient nutrition. One of the factors in the occurrence of stunting is due to risky pregnancies such as pregnancy at a young age, a lack of knowledge of mothers about health and nutrition before and during pregnancy, and after giving birth. Community service efforts were carried out in Mayangrejo, Kalitidu, Bojonegoro to reduce the incidence of stunting. Community service is carried out in the form of implementing educational activities and socializing adolescent reproductive health to 11 and 12 grade students of Al-Aly Islamic High School, Mayangrejo, Kalitidu so that they can be responsible for their reproductive health and their future. This community service activity is expected to increase the knowledge and understanding of adolescents related to reproductive health and the impact of marriage and pregnancy at too young age so that it can reduce the prevalence rate of stunting toddlers in Mayangrejo.
\end{abstract}

Keywords: Adolescent, Socialization, Stunting

\section{abstrak}

Periode 1000 hari pertama sering disebut window of opportunities atau sering juga disebut periode emas (golden period) yang merupakan penentu kualitas kesehatan pada masa kehidupan selanjutnya. Sayangnya, dalam setiap 1000 HPK ditemukan berbagai gangguan kesehatan yang mempengaruhi kesehatan bayi, salah satunya masalah bayi pendek atau stunting. Stunting adalah salah satu keadaan malnutrisi yang berhubungan dengan ketidakcukupan zat gizi. Salah satu faktor terjadinya stunting karena kehamilan yang berisiko seperti kehamilan usia terlalu muda, kurangnya pengetahuan ibu mengenai kesehatan dan gizi sebelum dan pada masa kehamilan, serta setelah ibu melahirkan. Upaya pengabdian masyarakat dilakukan di Desa Mayangrejo, Kecamatan Kalitidu, Kabupaten Bojonegoro untuk mengurangi kejadian stunting. Pengabdian masyarakat dilakukan berupa pelaksanaan kegiatan edukasi dan sosialisasi kesehatan reproduksi remaja kepada siswa kelas 11 dan 12 SMA Islam Al - Aly, Desa Mayangrejo, Kalitidu agar dapat bertanggung jawab terhadap kesehatan reproduksi dan masa depan mereka. Kegiatan pengabdian masyarakat ini diharapkan dapat meningkatkan pengetahuan dan pemahaman remaja terkait kesehatan reproduksi dan dampak dari pernikahan dan kehamilan usia terlalu muda sehingga dapat menekan angka prevalensi balita stunting di Desa Mayangrejo 
Kata Kunci: Remaja, Sosialisasi, Stunting

\section{PENDAHULUAN}

Kesehatan adalah harta yang paling berharga bagi manusia, karena itu setiap masyarakat berhak mendapatkan pelayanan kesehatan yang memadai untuk mencapai derajat kesehatan yang optimal. Derajat kesehatan yang optimal melalui peningkatan kesadaran, kemauan, dan kemampuan hidup sehat setiap orang merupakan salah satu tujuan utama pembangunan kesehatan di Indonesia.

Periode 1000 hari pertama sering disebut window of opportunities atau sering juga disebut periode emas (golden period) didasarkan pada kenyataan bahwa pada masa janin sampai anak usia dua tahun terjadi proses tumbuh kembang yang sangat cepat dan tidak terjadi pada kelompok usia lain. Pemenuhan asupan gizi pada 1000 HPK anak sangat penting. Jika pada rentang usia tersebut anak mendapatkan asupan gizi yang optimal maka penurunan status gizi anak bisa dicegah sejak awal (Rahayu, A dkk. 2018).

Selama 1000 HPK, periode dalam kandungan (280 hari), Ibu hamil berhubungan dengan proses pertumbuhan, yaitu pertumbuhan janin yang dikandungnya dan pertumbuhan berbagai organ tubuhnya sebagai pendukung proses kehamilannya tersebut sehingga kebutuhan nutrisi sebagai sumber energi ibu hamil bertambah.

Stunting (kerdil) adalah kondisi dimana balita memiliki panjang atau tinggi badan yang kurang jika dibandingkan dengan umur. Kondisi ini diukur dengan panjang atau tinggi badan yang lebih dari minus dua standar deviasi median standar pertumbuhan anak dari WHO. Stunting adalah salah satu keadaan malnutrisi yang berhubungan dengan ketidakcukupan zat gizi masa lalu sehingga termasuk dalam masalah gizi yang bersifat kronis. Salah satu faktor terjadinya stunting karena kurangnya pengetahuan ibu mengenai kesehatan dan gizi sebelum dan pada masa kehamilan, serta setelah ibu melahirkan (Sutarto, dkk. 2018).

Berdasarkan Peraturan Menteri Kesehatan Nomor 97 Tahun 2014 tentang Pelayanan Kesehatan Masa sebelum Hamil, Masa Hamil, Persalinan, dan Masa Nifas, Penyelenggaraan Pelayanan Kontrasepsi, serta Pelayanan Kesehatan Seksual, faktorfaktor yang memperburuk kondisi ibu hamil adalah terlalu muda, terlalu tua, terlalu sering melahirkan, dan terlalu dekat jarak kelahiran. Usia kehamilan ibu yang terlalu muda (di bawah 20 tahun) berisiko melahirkan bayi dengan berat lahir rendah (BBLR). Bayi BBLR mempengaruhi sekitar 20\% dari terjadinya stunting.

Kondisi kesehatan dan gizi ibu sebelum dan saat kehamilan serta setelah persalinan mempengaruhi pertumbuhan janin dan risiko terjadinya stunting. Gizi pada masa kehamilan merupakan salah satu faktor penting yang mempengaruhi perkembangan janin serta status kesehatan ibu hamil. Kehamilan merupakan tahapan yang berkesinambungan, sehingga defisiensi pada suatu periode akan memberikan dampak secara berbeda pada outcome kehamilan. Faktor lainnya pada ibu yang mempengaruhi adalah postur tubuh ibu (pendek), jarak kehamilan yang terlalu dekat, ibu yang masih remaja, serta asupan nutrisi yang kurang pada saat kehamilan. Kondisi ibu sebelum masa kehamilan baik postur tubuh (berat badan dan tinggi badan) dan gizi merupakan salah satu faktor yang mempengaruhi terjadinya stunting. Remaja putri sebagai calon ibu di masa depan seharusnya memiliki status gizi yang baik. 
Menurut hasil Riskesdas tahun 2007, provinsi Jawa Timur merupakan salah satu dari 10 provinsi di Indonesia dengan prevalensi KEK penduduk wanita usia subur di atas prevalensi nasional (13,6\%). Sementara hasil Riskesdas tahun 2013 menunjukkan bahwa prevalensi penduduk wanita usia subur (usia 15-49 tahun) sedang hamil dan mengalami risiko KEK di Jawa Timur sebesar 29,8\%, sedangkan di tingkat nasional prevalensi penduduk WUS yang sedang hamil dan mengalami risiko KEK sebesar $24,2 \%$. Hal ini menunjukkan bahwa penduduk WUS yang sedang hamil dan KEK di Jawa Timur masih lebih tinggi daripada di tingkat nasional. Menurut data Riskesdas pada tahun 2017, angka stunting di Jawa Timur masih mencapai angka diatas 30\%.

Kabupaten Bojonegoro merupakan salah satu kabupaten yang terletak di Jawa Timur. Kabupaten Bojonegoro terdiri dari 28 kecamatan, dimana terdapat 419 desa dan 11 kelurahan (Widodo, Warsito and Wulandari 2018). Menurut penelitian Laksono \& Megatsari (2020), prevalensi balita stunting di Bojonegoro yang tergolong kategori rendah dimana kategori rendah adalah jika angka prevalensi di bawah $14 \%$. Pada tahun 2019 prevalensi balita stunting di Bojonegoro adalah sebesar 7,45\%

Desa Mayangrejo Kecamatan Kalitidu merupakan salah satu wilayah dari Kabupaten Bojonegoro. Desa Mayangrejo memiliki penduduk sebanyak 3411 jiwa, dan sebanyak 445 jiwa merupakan balita. Dengan menggunakan rumus perhitungan gizi untuk mengetahui prevalensi perhitungan stunting adalah tinggi badan menurut usia (TB/U), didapatkan jumlah balita stunting di Desa Mayangrejo sebanyak 57 balita. Dapat disimpulkan dari jumlah balita yang mengalami stunting di Desa Mayangrejo sebesar $12,8 \%$

Tingkat pendidikan umum terbanyak yang telah didapatkan oleh ibu balita stunting diantaranya adalah Sekolah Dasar (SD)/Sederajat sebanyak 33 orang, Sekolah Menengah Pertama (SMP)/Sederajat sebanyak 14 orang, Sekolah Menengah Atas (SMA)/Sederajat sebanyak 9 orang dan Penduduk yang tamat S-1 terdapat 1 orang.

Kegiatan pengabdian masyarakat pada kali ini melaksanakan program sosialisasi dan pelatihan teori kesehatan reproduksi pada siswa SMA agar mereka dapat memahami dampak dari pernikahan dan kehamilan dini sehingga mereka dapat mempersiapkan fisik, mental, pendidikan dan pengetahuan serta berbagai hal lain sebelum memutuskan untuk menikah. Tujuan dari kegiatan pengabdian masyarakat yang dilaksanakan adalah sebagai salah satu bentuk upaya untuk menurunkan angka stunting di Desa Mayangrejo dengan meningkatkan pengetahuan remaja berkaitan dengan kesehatan reproduksi agar memotivasi pelajar menjadi remaja yang bertanggung jawab terhadap kesehatan reproduksi dan masa depan mereka.

\section{METODE PENGABDIAN MASYARAKAT}

Kegiatan pengabdian masyarakat yang dilaksanakan merupakan hasil kerja sama antara mahasiswa, kader kesehatan Desa Mayangrejo, bidan desa, perangkat desa, pihak sekolah terkait dan pihak Universitas Airlangga. Kegiatan yang dilaksanakan adalah:

\section{Sosialisasi}

Kegiatan ini dilaksanakan dengan tujuan untuk meningkatkan pengetahuan siswa SMA untuk memahami pentingnya kondisi kesehatan reproduksi agar memotivasi mereka 
menjadi remaja yang bertanggung jawab terhadap kesehatan reproduksi dan masa depan mereka. Materi sosialisasi yang diberikan berkaitan dengan kesehatan reproduksi remaja dimana kegiatan ditujukan kepada siswa kelas 11 dan 12 SMA Islam Al - Aly. Pengisi materi dari kegiatan adalah mahasiswa yang didampingi oleh perwakilan guru SMA Islam Al - Aly. Analisis data yang dilakukan dalam kegiatan ini yaitu dengan menggunakan pre test dan post test terkait dengan pengetahuan remaja terhadap kesehatan reproduksi.

\section{HASIL DAN PEMBAHASAN}

Kegiatan pengabdian masyarakat dilaksanakan di Desa Mayangrejo, Kecamatan Kalitidu, Kabupaten Bojonegoro. Desa Mayangrejo berbatasan dengan Desa Pilangsari di sebelah utara, Desa Mojosari di sebelah timur, Kecamatan Ngasem di sebelah selatan, dan Desa Panjunan di sebelah barat. Desa Mayangrejo terdiri atas 5 dusun yaitu dusun Slembi, dusun Gempol, dusun Ngenden, dusun Talun, dan dusun Crabak. Jumlah seluruh warga Desa Mayangrejo pada akhir tahun 2018 adalah sebanyak 3.411 orang yang terdiri atas laki - laki sebanyak 1.781 orang dan perempuan sebanyak 1.630 orang yang tersebar di 5 dusun, 22 RT dan12 RW.

\section{Kegiatan Pengumpulan Data}

Masalah terkait kesehatan yang dihadapi balita di Desa Mayangrejo adalah balita pendek. Berdasarkan permasalahan tersebut maka perlu diketahui akar permasalahannya, yang akan dijadikan latar belakang untuk menentukan program yang akan dilaksanakan. Data sekunder diperoleh dari data di Puskesmas Kalitidu, Ponkesdes Mayangrejo serta Kantor Desa Mayangrejo yang dijadikan bahan dasar dalam diagnosis dan identifikasi masalah. Data primer yang berkaitan dengan penentuan akar masalah dikumpulkan melalui kegiatan Metaplan, in- depth interview, dan kuesioner (observasi).

Metaplan dilaksanakan bersama dengan kader posyandu dari 5 dusun di Desa Mayangrejo untuk mengetahui kondisi penduduk desa terutama keluarga yang memiliki balita pendek. Metaplan dilaksanakan sebanyak 1 kali dengan jumlah kader sebanyak 10 anggota kader beserta Bidan Desa sebagai koordinator kader. Berdasarkan hasil Metaplan dapat diketahui bahwa permasalahan terjadinya stunting di Desa Mayangrejo didasari oleh berbagai hal, antara lain kurangnya pengetahuan masyarakat sehingga banyak terjadinya pernikahan dini, kurangnya pengetahuan ibu mengenai pemberian MP - ASI yang tepat, ibu balita kurang memberikan asupan makanan yang bergizi untuk anaknya dan juga ibu pada saat hamil.

Selain kegiatan Metaplan, dilaksanakan juga kegiatan indept interview. Kegiatan ini dilakukan untuk mendapatkan informasi yang lebih mendalam mengenai isu yang ada di masyarakat dan data tentang kesehatan masyarakat di Desa Mayangrejo. Indepth interview dilakukan bersama dengan narasumber yaitu bidan dan perawat Ponkesdes Mayangrejo, pegawai unit kesehatan lingkungan Puskesmas Kalitidu, kepala dusun setempat. Pertanyaan yang diajukan untuk melakukan indepth interview telah disusun dalam bentuk panduan wawancara untuk memudahkan proses indepth interview.

Kuesioner juga disebar untuk mendapatkan data yang diinginkan. Populasi dari 
kegiatan penyebaran kuesioner adalah keluarga yang memiliki balita di Desa Mayangrejo. Sampel yang digunakan adalah sebanyak 57 keluarga yang memiliki balita. Pertanyaan yang diajukan dalam kuesioner antara lain adalah karakteristik responden, karakteristik dan antropometri balita, karakteristik keluarga, pendapatan rumah tangga, perilaku terhadap pelayanan kesehatan, pola asuh, pola makan, dan sanitasi lingkungan dan personal hygiene. Berdasarkan kegiatan penyebaran kuesioner diketahui bahwa permasalahan yang dihadapi oleh masyarakat berkaitan dengan gizi anak adalah rendahnya pendidikan dan pengetahuan ibu balita terkait gizi pada balita.

\section{Kegiatan Penentuan Akar Masalah}

Hasil dari kegiatan Metaplan, in-depth interview, dan wawancara kuesioner kemudian dipilah untuk menemukan akar masalah dengan menggunakan metode fishbone (tulang ikan). Indikator yang digunakan untuk pemilahan hasil kegiatan Metaplan adalah 5M, yaitu machine, method, man, money, dan material. Berdasarkan pemilahan tersebut, akar masalah yang menjadi dasar penentuan alternatif solusi adalah, indikator Perilaku Hidup Bersih dan Sehat (PHBS) dan indikator Keluarga Sehat yang belum terpenuhi, pola asuh balita oleh ibu, tingkat pendidikan ibu balita yang terbilang rendah, dan pengelolaan sampah oleh masyarakat yang masih buruk, kurangnya pengetahuan calon pengantin, kurangnya tenaga kader, dan kurangnya anggaran untuk pengeloalaan sampah.

Berdasarkan akar masalah tersebut maka terdapat sebanyak 8 alternatif solusi. Alternatif solusi yang didapatkan antara lain memberikan edukasi pada calon pengantin, menambah sumber daya keuangan, pemberdayaan masyarakat dalam pengelolaan sampah, memberikan motivasi pada ibu hamil, menjalin kerja sama dengan tokoh masyarakat, memberikan edukasi pada remaja, memberikan latihan keterampilan, membuat media sosialisasi yang sesuai dengan sasaran

\section{Kegiatan Penentuan Prioritas Alternatif Solusi}

Alternatif solusi yang telah ditemukan, kemudian ditentukan prioritasnya menggunakan metode Methodology, Effectivity, Efficiency, and Relevancy (MEER). Metode MEER merupakan metode yang dapat digunakan untuk menentukan prioritas dari alternatif solusi. Indikator dalam metode MEER adalah (1) Metodologi: tolak ukur berkaitan dengan kemudahan dalam penerapan teknologi tepat guna, (2) Efektivitas: Berkaitan dengan tolak ukur keberhasilan strategi yang dirancang yang ditujukan untuk mencapai tujuan, (3) Efisiensi: berkaitan dengan besaran dukungan yang dibutuhkan, (4) Relevansi: berkaitan dengan kesesuaian strategi yang dirancang dengan kegiatan organisasi (Nurdianna 2018).

Hasil dari perhitungan menggunakan metode MEER, telah ditentukan rangking tertinggi hingga terendah berdasarkan jumlah nilai pada tiap indikator. Alternatif solusi yang diprioritaskan berdasarkan metode MEER yaitu kegiatan pemberian edukasi terkait kesehatan reproduksi atau pengetahuan kepada remaja. 


\section{Lokasi, Waktu Pelaksanaan, dan Durasi}

Kegiatan pemberian edukasi pada remaja dilaksanakan di SMA Islam Al - Aly Mayangrejo, Kalitidu. Kegiatan sosialisasi dilaksanakan pada Senin, 27 Juli 2019 pukul 10.35-11.40 WIB.

\section{Kegiatan Edukasi Kesehatan Reproduksi pada Remaja}

Kegiatan sosialisasi berkaitan dengan kesehatan reproduksi pada remaja dilaksanakan sebanyak satu kali pada tanggal 27 Juli 2019 pukul 10.35-11.40 WIB. Sasaran dari kegiatan sosialisasi adalah murid SMA Islam Al - Aly Mayangrejo, Kalitidu. Kegiatan sosialisasi diadakan berupa pemaparan materi terkait kesehatan reproduksi remaja dengan tujuan meningkatkan pengetahuan siswa kelas 11 dan 12 SMA Islam Al - Aly Mayangrejo, Kalitidu terkait kesehatan reproduksi serta dampak pernikahan dini agar memotivasi pelajar menjadi remaja yang bertanggung jawab terhadap kesehatan reproduksi dan masa depan diri mereka dan terus berprestasi, melakukan hal yang positif, serta menjadi pribadi yang bermanfaat bagi nusa dan bangsa

Tolak ukur yang digunakan sebagai acuan ada atau tidaknya peningkatan pengetahuan siswa adalah menggunakan metode pre test dan post test. Kegiatan sosialisasi juga ditunjang dengan pembagian reward kepada siswa yang dapat menjawab pertanyaan terkait materi sosialisasi yang sudah disampaikan pada akhir kegiatan.

Jumlah siswa yang hadir dalam kegiatan sosialisasi sebanyak 46 dari total 65 siswa atau sebesar $71 \%$ kehadiran. Siswa yang hadir dalam kegiatan sosialisasi mengikuti kegiatan pre test dan post test untuk mengetahui adanya peningkatan pengetahuan. Kisaran nilai pre test dari siswa adalah 20-90. Sedangkan kisaran nilai post test dari siswa adalah 50 - 100. Berdasarkan hasil dari pre test dan post test terdapat peningkatan nilai dimana rata-rata nilai dari pre test adalah sebesar 50,9. Sedangkan nilai rata-rata pada post test adalah sebesar 84,1, sehingga mereka mengalami peningkatan pengetahuan sebesar $33,26 \%$. Peningkatan hasil nilai pre test dan post test menandakan adanya peningkatan pengetahuan dan pemahaman siswa terkait kesehatan reproduksi dan dampak dari pernikahan dini.

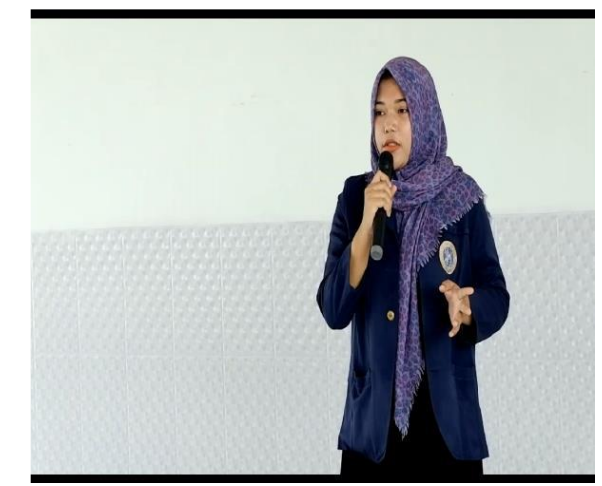

Gambar 1. Kegiatan Sosialisasi Al-Aly

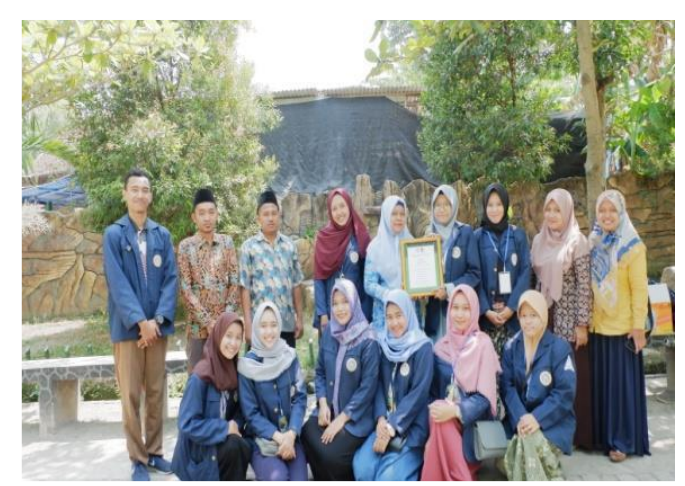

Gambar 2. Foto bersama pihak SMA Islam 


\section{PENUTUP}

\section{Simpulan}

Kegiatan pengabdian masyarakat dilaksanakan di Desa Mayangrejo, Kalitidu, Bojonegoro.Sasaran utama dari pelaksanaan kegiatan pengabdian masyarakat adalah berkaitan dengan kesehatan balita. Tujuan dari kegiatan pengabdian masyarakat adalah sebagai salah satu bentuk upaya untuk menurunkan angka stunting di Desa Mayangrejo dengan meningkatkan pengetahuan kesehatan reproduksi remaja sehingga dapat mengurangi kejadian menikah dan kehamilan usia dini yang menjadi salah satu penyebab stunting. Data untuk merancang program adalah menggunakan data primer yang didapatkan dari kegiatan metaplan, indept interview, dan kuisioner (observasi). Data tersebut kemudian diolah untuk diketahui akar permasalahan menggunakan metode fishbone atau tulang ikan. Setelah akar permasalahan diketahui, kemudian ditentukan alternatif solusi dari tiap akar masalah. Alternatif solusi tersebut kemudian ditentukan prioritasnya menggunakan metode MEER. Hasil dari perhitungan metode MEER, diketahui bahwa prioritas alternatif solusi dari akar masalah yang ada adalah sosialisasi atau edukasi pada remaja berkaitan dengan kesehatan reproduksi remaja. Materi yang telah disusun pada kegiatan yang dilaksanakan diharapkan dapat dipahami oleh remaja sehingga mereka dapat terus mengasah pengetahuan dan pendidikan mereka agar dapat menekan angka stunting di Desa Mayangrejo.

\section{Saran}

Saran yang diusulkan oleh tim pelaksana program pengabdian masyarakat adalah: 1) Kegiatan sosialisasi kesehatan reproduksi remaja dilakukan secara rutin karena setiap tahun murid selalu berganti. 2) Perangkat pemerintahan di Desa Mayangrejo dapat ikut berpartisipasi dalam upaya peningkatan derajat kesehatan khususnya kesehatan balita di Desa Mayangrejo. 3) Masyarakat Desa Mayangrejo dapat berpartisipasi dalam memberikan perhatian lebih terhadap kesehatan khususnya kesehatan reproduksi remaja di Desa Mayangrejo

\section{DAFTAR PUSTAKA}

Bappenas RI. Kerangka Kebijakan Gerakan Nasional Percepatan Perbaikan dalam Rangka Seribu Hari Pertama Kehidupan (Gerakan 1000 HPK). Jakarta: Bappenas RI, 2013.

Kementerian Kesehatan RI. Peraturan Menteri Kesehatan Nomor 97 Tahun 2014 tentang Pelayanan Kesehatan Masa sebelum Hamil, Masa Hamil, Persalinan, dan Masa Nifas, Penyelenggaraan Pelayanan Kontrasepsi, serta Pelayanan Kesehatan Seksual. Jakarta: Kementerian Kesehatan RI, 2014.

Kementerian Kesehatan RI. Riset Kesehatan Dasar. Jakarta: Kementerian Kesehatan RI, 2018.

Laksono, Agung Dwi, and Hario Megatsari. "Determinan Balita Stunting di Jawa Timur: Analisis Data Pemantauan Status Gizi 2017." Amerta Nutrition 4, no.2 (2020).

Sutarto, Diana Mayasari, Reni Indriyani. Stunting, Faktor Risiko dan Pencegahannya. 
Astri Dewi Choirina : Peningkatan Pengetahuan Murid SMA Terkait Kesehatan Reproduksi Untuk Mencegah Stunting Di Desa Mayangrejo, Kalitidu

J Agromedicine Volume 5 Nomor 1, 2018: 540-545.

Widodo, Oky Setyo, Sunaryo Hadi Warsito, and Shelly Wulandari. "Peningkatan Kesehatan Masyarakat Melalui Pengetahuan Penyakit Zoonosis di Kecamatan Kepohbaru Kabupaten Bojonegoro." Jurnal Layanan Masyarakat UniversitasAirlangga, 2018: 56-59.

Profil Desa Mayangrejo Kecamatan Kalitidu Kabupaten Bojonegoro Tahun 2018.

Rahayu, A., Fauzie Rahman, Lenie Marlinae, Husaini, Meitria, Meitria, Dian Rosadi, Nur Laily. BUKU AJAR GIZI 1000 HARI PERTAMA KEHIDUPAN. Yogyakarta. CV Mine. 2018.

Pusdatin.Buletin Jendela Data dan Informasi Kesehatan.Jakarta. Pusdatin, 2018.

Azizah, Anisatun dan Merryana Adriani. TINGKAT KECUKUPAN ENERGI PROTEIN PADA IBU HAMIL TRIMESTER PERTAMA DAN KEJADIAN KEKURANGAN ENERGI KRONIS. Media Gizi Indonesia, Vol. 12, No. 1. 2017: hlm. 21-26. 